13. Raykovska, G. O. (2011). Teoretyko-metodychni zasady hrafichnoi pidhotovky maibutnikh fakhivtsiv tekhnichnykh spetsialnostei zasobamy informatsiinykh tekhnolohii [The development of the students' technical thinking in the process of the mechanical drawing study]. Kyiv, 46.
14. Sydorenko, V. K. (1995). Intehratsiia trudovoho navchannia i kreslennia yak zasib rozvytku tekhnichnykh zdibnostei shkoliariv [The integration of labor studies and drawings as means of technical abilities of students]. Kyiv, 350.

Рекомендовано до публікаиії д-р пед. наук, професор Оршанський Л. В. Дата надходження рукопису 18.02.2016

Нищак Іван Дмитрович, кандидат педагогічних наук, доцент, кафедра методики трудового і професійного навчання та декоративно-ужиткового мистецтва, Дрогобицький державний педагогічний університет ім. Івана Франка, вул. І. Франка, 24, м. Дрогобич, Україна, 82100

E-mail: nyshchak@gmail.com

\author{
УДК 378.37:27-047.64 \\ DOI: $10.15587 / 2313-8416.2016 .64075$
}

\title{
MODERN TENDENCIES AND PROBLEMS OF THE THEORY OF SPIRITUAL-MORAL PROCESSES MANAGEMENT IN HIGHER SCHOOL
}

\section{(C) I. Sidanich}

In the article were analyzed the modern tendencies and problems of the theory of spiritual-moral processes management in the higher school. There were defined the node tasks of reformation of higher education: ensuring its quality, construction of effective educational system of the higher school institutions with effective economy and management. There was characterized the problem of ensuring axiological direction of spiritualhumanitarian component of educational process in the system of higher education. There were defined priorities of national interests in spiritual-moral education of junior generation in the state educational activity: national self-consciousness, spiritual-cultural unity of nation, patriotism, humanism, tolerance, responsibility.

There was analyzed the system of higher education in the aspect of interaction of spiritual and secular components in coordinates of moral sanitation and spiritual enlightenment of nation, elaboration of democratic principles of society and construction of the modern theory of spiritual-moral processes management in higher school. There were defined the new directions of the theory of spiritual-moral processes management in higher school in the aspect of development of innovations and commercialization, attraction of employers to collaboration with scientists in separate work groups for creation of the new educational programs and modernization of existing ones, mentor support and training of students for job placement and development of enterprising skills and also for support of the programs of probation or practical participation of students in the "real social projects".

There were characterized prospects of research in the aspect of elaboration of the main functions that must establish the main claims to production tasks in professional activity of holder of the master's degree on speciality "Christian pedagogics in the high education"

Keywords: theory of spiritual-moral processes management, spiritual policy in higher education

У статті проаналізовано принципи проведення державними органами духовно-моральної політики у вищій освіті, визначено сучасні тенденщії і проблеми теорії управління духовно-моральними процесами у вищій школі. Охарактеризовано особливості впровадження магістерської програми «Християнська педагогіка у вищій школі» у вищому навчальному закладі. Визначено пріоритети духовно-морального виховання: національна самосвідомість, духовно-культурна єдність нації, народу, патріотизм, гуманізм, толерантність, відповідальність

Ключові слова: теорія управління духовно-моральними процесами, духовна політика у вищій освіті

\section{Introduction}

During the years of independence the system of higher education ,survived" the processes of transformation (in political, social and economic directions), liberalization, optimization that favored the formation of the market of educational services (MES). For today the main strategic direction of educational policy is modernization of the higher education that must spread on the structure of higher education and organization of educational process, on the content of educational programs and on the management of higher educational institution.
The complications of social-economic and political development of the country impressed the junior generation painfully. The spirituality level declines among children and young people that can be explained by the lowering of the living standards in Ukraine, absence of social protection, evident and hidden unemployment, inflation, uncertainty of moral orientations in state policy and routine life. Mass media more and more influence society especially young people propagandizing violation, arm, force, inoculating moral relativism, conformism, cynical-hedonistic relation to commonness. 
Transformational processes of the last decade in Ukraine are characterized with the serious miscalculations in elaboration of state. Defiance of the spiritual component of social development by the state authorities resulted in contradictions not only in spiritual-moral sphere but also in social-economic development and cultural-educational sphere. That is why the new Ukrainian authorities encounter with the important tasks as to overcoming the economic, social, legal, political, educational contradictions. But the initial link of all these transformations must be the spiritual sanitation of nation because only "the high level of national self-consciousness and correspondent social and political activity of nation is the single true guarantee of solving the all complex of imminent social problems" [1].

In this connection for today it becomes topical to analyze the modern tendencies and problems of spiritualmoral processes management in higher school, creation of the theoretical management model of influence on formation and development of spiritual values in students with clear definition of aims, tasks, principles, directions of activity and the main subjects of HEI (higher educational institution) management that provide the realization of this model.

According to L. Grinevich Ukraine is historical part of European Christian space and in this connection there are some ideas that are also fundamentally interwoven in canvas of Ukrainian education. And that is why we must think about how the Christian ideas can be integrated in educational conception of Ukrainian higher school. On the example of Ukrainian catholic university that trains specialists for the different life spheres the scientist-politician thinks that it is the beautiful mission not only to form in the system of higher education the highly qualified specialist but also to bring up Ukrainian citizen that will follow also the Christian values in its professional life [2].

\section{Stating of problem}

The actual directions of the search for new managerial ideas that must be the ground of the modern theory of spiritual-moral processes management in higher school are the determination of priority values, aims and norms of management process. The aim of the article is an analysis of principles of spiritual-moral policy in higher education carried out by the state authorities and also revelation of peculiarities of spiritual-moral processes management in higher school.

\section{Literature review}

The problems of managerial influence on spiritual-moral sphere were an object of studies of many native scientists. Last years there was defined the tendency to increase of scientific studies on the problem of higher education management from the positions of anthropocentric approach to the subjects of educational process that is the result of social changes in the process of education humanization. It was elucidated in the works of $\mathrm{V}$. Bech [3], V. Kononenko [1], V. Lugovoy [4], V. Olijnik [5], V. Skurativskiy [6], P. Tretiakov. In chain of researches there was grounded humanocentric and sociocentric reorientation of education within market society on satisfaction of personal and social needs proceeding from the tendency of development of postmodern social and educational practices. It is demonstrated in works of V. Andruschenko [7], L. Gninevich [2], V. Kremen [2], V. Kutsenko [2], V. Lutay, M. Mikhalchenko [8], I. Nadolniy [9]. At the same time let us note that it is not a proper time to think that the problem of determination and systematization of education management principles is solved, so it seems urgent to carry out the theoretical analysis and use the principles of spiritual-moral processes management in high school on practice.

Especially in the modern scientific researches the problem of using principles of spiritual-moral processes management in higher school is not completely demonstrated.

\section{Analysis of the modern tendencies and prob- lems of spiritual-moral processes management in higher school}

First of all it must be noted that spiritual-moral processes management in the higher school needs in the first place the distinct determination of its structural components. For organization of management process it is necessary first of all to separate the objects and subjects of managerial influence that provide its realization and fulfillment of set tasks at certain stages or during all the process for attaining the set aim. The realization of managerial activity in spiritual-moral sphere is not an exception though it has its specificity. This specificity consists in the fact that influence of spiritual-moral processes management in the higher school presupposes systematization of principles of spiritual-moral processes management in the higher school, determination of priority values, aims and norms of management process and creation of conditions for self-development and selforganization of students.

The native system of high pedagogical education made the essential step in its dynamic development as to transforming student from the object into subject, establishing the subject-subject relations in educational process. At the same time the student unfortunately remains the subject of education but not the subject of future professional activity. It means that the modern system of higher pedagogical education became more democratic but it does not bring student to the level of professional maturity. In the conditions of accelerated obsolescence of knowledge and introduction of the new educational technologies it is necessary to practically elaborate the mechanisms of management of active and qualitative spiritualmoral education and self-education of HEI students. The most important claim for content of the spiritual-moral education and self-education is the use of modern informational means, computer technologies, the refusal of giving the completely finished information to the students and on the contrary involving them to its search and processing, the important role plays the quality of its renewal, at the same time must be stimulated the personal perception of material, critical assessment, introduction of personal experience, active mutual education.

The shift of accents in HEI activity from organizational-structural tasks to the ones of quality of scientific-researching and educational work, the quick reaction 
of higher school on emerging social problems gave an opportunity to elaborate the recommendations for improvement and increase of effectiveness of spiritualmoral processes management in the higher school accordingly to the new conditions:

- HEI development on the base of organization principles (the high level of "team administration" that is association of adherents that understands and share the administrative strategy and tactics; organization of permanently acting programs of spiritual-moral direction and systemic introduction of educational innovations; actual practice of experience exchange and replication of positive pedagogical, didactic, methodical ways; the system of attraction teachers working according to innovative methods of spiritual-moral content);

- system of administration oriented on the highly spiritual philosophy, organizational spiritual-moral culture and innovations of scientific-pedagogical and methodical HEI stuff;

- declaration of Christian mission and corporative philosophy that excludes manufacturability of educational processes because it does not regulate an activity of its participants (teacher plays the role of adviser, skilled specialist in concrete educational subject who tries to help students in attainment of the final aim of educational process - obtaining knowledge and skills;

- competitive ability of the higher educational institution that gives the quality of education, spiritualmoral training, organization of educational institution as the open type system (monitoring of environment, study of labor market for detection of the new prospective directions of training specialists, analysis of development tendencies of the one or another subject sphere for collecting and elaborating information for teaching the correspondent educational subjects;

- the control of the education quality for objective assessment and accepting managerial decisions in creation of the modern higher school which main indicator is the personal spiritual-moral values, stable fitness for the job placement and successful work of graduated student of the higher school in chosen sphere of labor activity and also for the further development [10].

An influence on formation and development of spiritual-moral values of students is evolutional and needs the accurate interaction and understanding between all its subjects [4]. Administrative influence on spiritualmoral sphere of the higher school is realized through the fulfillment of humanitarian policy. Humanitarian policy is the system of principles, aims, mechanisms and successive measures that directed on creation of conditions of social-humanitarian development of society, social and intellectual-spiritual safety of person and society, realization of its social and spiritual needs, formation and enrichment of personal creative potential, thorough selfrealization of essential forces, sociodynamics of education, science, culture and so on. The main components of humanitarian policy are the state educational and scientific, cultural, language, informational, ethno-national, religious policy, the policy of health protection sphere, tourism, physical culture and sport [6].

The main task of humanitarian policy in spiritualmoral sphere of the higher school is the creation of con- ditions for the most complete learning by students the multiform potential of Ukrainian and international spirituality and culture. It is extremely important also to create conditions for thorough self-realization of spiritualcultural potential, personal essential forces, own spiritual view and perception of the world [9].

The new educational paradigm that reflects the displacement of accents from educational process to its final results must become the base of state policy in higher education sphere. Humanitarian dimension of the higher education opens prospect for the real democratism of educational process. The construction of system of higher education management according to the principles of anthropocentrism and humanitarian paradigm in education will favor the attainment of these aims.

According to V. Kremen anthropocentrism is the philosophy of humanity oriented approach to the social relations and person. It must be directed on overcoming of the internal emptiness, practical destruction of consciousness and world-view. Development of the anthropocentric philosophy and its introduction to life practice is one of the main conditions of formation and settling of the modern system of social help and socially oriented state [5]. The system of principles of social state development presupposes that human, its development and self-realization is the main value in this conception. We can affirm that social state acts for people and for the sake of people and that are people who reproduce its main principles and ideas [11].

E. Ryabchenko analyzing the special features of realization of anthropocentric philosophical principle in the higher education management separates the following levels of higher education management: the first level strategic management of higher education (management of higher education aims); the second one - management of processes (management of development, functioning and so on); the third one - organizational management (management of structural transformation, stuff, resources and so on). Proceeding from it, the researcher considers the motivational function according to which the subject of educational process is first of all the person who seeks for self-realization and self -improvement as an important function of management [12].

According to the author the use of anthropocentric principle in higher education management is directed on: formation of free and responsible person; formation of world-view sets, ideas, values that are common to mankind; guaranteeing of condition for the free selfdetermination of every person in world-view space for accepting by it the own values in the form of life aims, main motivations and interests, aspirations, needs, principles and so on [12].

In our opinion the V. Kutsenko's concept of management of the labor stuff at enterprise based on the Christian grounds is rather interesting. The researcher presupposes the mission of economic management in creation of harmonic relations between working persons; management principles are in spiritual-moral unity, goodwill, openness and transference of the gained experience, social responsibility, catharsis, peace coexistence and collaboration with the other subjects of economy (self-guaranteeing especially self-financing, self-suffi- 
ciency and self-satisfaction). The main aim of labor association the author finds in guaranteeing of stable (lifegiving) development; and the main methods of management are socio-psychological and spiritual-moral. The scientist offers her personal example of friendly attitude to people, responsible execution of her duties as the base of influence on subordinates; the ways for attaining the aim - spiritual revival of person, labor association and society as the guarantee of professionalism and acceptance of the correct economic decisions [8].

The researcher thinks that only in these conditions the management will be effective and will lead to the stable (life-giving) development of Ukrainian society. But for realization of these principles the following tasks must be carried out: the state must elaborate and introduce the termless Program of spiritual-moral development of society starting from publication of the correspondent educational literature, training and re-training in Ukrainian HEI the specialists: catechists, theologians, organization of spiritual-moral education of children (in families and schools), adults (at enterprises, organizations, in mass media and so on). Spirituality is the guarantee of gaining the qualitative professional knowledge of students and labor skills of specialists.

An analysis of principles of carrying out of spiritual-moral policy in higher education by the state authorities gives a possibility to discover the special features of spiritual-moral processes management in SHEI "University of education management" of NAPS of Ukraine. Educational process in magistracy on speciality "Christian pedagogics in the higher school" built on humanization principles conditions taking into account personal aims and interests of the future teachers of Christian pedagogics, filling of educational subjects of spiritual-moral direction with the humanized content, the use of active methods and forms of education when gaining knowledge realizes in the process of search for truth, clash of thoughts, opinions, positions, development of self-control and self-assessment of students.

Realization of humanitarian education Conception in the Institute of management and psychology in the University of education management gives preference to the subject-subject educational process when undergraduate student is active, initiative, ready to the collective intellectual activity that can be realized for example with the help of problem-dialogue teaching. An activity of the future teachers of Christian pedagogics is attained through the feeling of internal freedom, acceptance of the right to the choice - right to finding of the own tempo of education, formation of package of educational subjects from the list of possible ones, participation in all accessible types of educational, scientific or other creative work. The aim of specialization is professional training of teachers for qualitative teaching of Christian pedagogics in educational institutions by the way of deepening of knowledge of Christian theology; development of corresponding abilities and skills with the help of educationalpedagogic practice in scientific, educational, penitentiary, medical, social, cultural, religious, consulting organizations and institutions; in subsections of state power bodies, municipal administration corresponding to the main speciality.
The use of education humanization principle in of management higher education on speciality "Christian pedagogics in the high school" needs the realization of certain tasks:

- Giving to the student the system knowledge about regular interconnections between person and nature, society, state; about processes of formation of person, its attitude to the other people and itself, guaranteeing of development of correspondent abilities and skills by the way of learning theoretical courses and carrying out educational-production practice;

- formation of abilities to assessment of social, cultural and natural phenomena, to gaining means for acquirement and interpretation of scientific information, its processing and storage; to see the "own" subject in educational process, to learn the grounds of Christian theology and Christian pedagogics that is necessary for acquiring qualification of the teacher of Christian pedagogics;

- mastering the system of anthropologic knowledge by the students that is gained in the process of learning psychological-pedagogical, socio-humanitarian and cultural educational subjects, preparation for the innovative creative activity directed on revival of values, the national ones and common to mankind in the conditions of constructing market economy;

- acquaintance with the modern state of humanitarian sphere of Ukraine, with normative-legal support of education and legislation base of teaching educational subjects of the spiritual-moral direction, with actual problems of safety of the personal life activity in society;

- gaining knowledge about individual-personal characteristics of students and teachers, ability to take it into account at teaching educational problems of spiritual-moral direction; forms and methods of educational activities in HEI, the out-of-school holiday actions with parents, pedagogical stuff, community;

- guaranteeing understanding by the future teachers of the essence of Christian tradition, peculiarities of Christian education including the spiritual-moral problems of Ukrainian society and differences of ethic instructions in the other religious doctrines.

All aforesaid have certain influence on improvement of professional training of undergraduate students. But the most essential factor of improvement of the level of specialist preparation is the realization of humanism principle. As far as humanism is the fulfillment of humanity in all diverse manifestations of the human behavior let us separate the one more component of the educational process humanization - the humane interrelations and communication, acknowledgement of interests and needs of the other person, an attention permanently directed on student's person, compassion and care, timely and unselfish help, mercy, kindness.

The base of humane relation is tolerance to another views, social traditions and customs, shame, feeling of blame, penitence, repentance, veneration for life, generosity and delicacy. All these components are organically connected with each other and its formation needs painstaking work. Before forming the humane relations we must develop the humane feelings. The active participation in the fate of the other person, compassion to other's misfortune, the enjoyment of the "other's joy" enrich and 
develop humanistic feelings. Actualization of emphatic processes (development of emotional receptivity, feeling of internal support of another person) realizes in the process of activity which content is the care and sympathy with the other persons $[6,12]$.

The scientific pedagogic worker must learn to love the other people - students, parents, colleagues. The teacher's ability to love depends on ability to overcome self-adoration, internal fight against indifferent attitude to the people and inclination for humiliation. At the same time to love always mean to know the person, to respect it, to bear the full responsibility of it, permanently care of it. In general aspect the functions of teacher and student as the partners in pedagogical communication are considered as following: teacher-partner is initiator of communication, its organizer, creative conductor of pedagogic conceptions prevalent at the certain level; studentpartner that actively reacts on pedagogical influence is interpreter, modifier and realizer of humane pedagogical conceptions.

Formation of specialists of the new generations must be grounded on principles of anthropocentrism, humanization, personally oriented educational process that gives a possibility to create such conditions when every student can feel itself a person and realize its subject possibilities for attaining individual educational aims. The final aim of educational process humanization in the higher school is the development of professionally trained moral-spiritual person.

\section{Approbation of the results of research}

Approbation of the results of research in SHEI "University of education management" of NAPS of Ukraine is realized by the way of introduction of magisterial program on specialization "Christian pedagogics in the higher school" on speciality 8.18010021 - pedagogics of the higher school. In the process of elaboration and approval of magisterial program at the academic council of the Educational-scientific institute of education management and psychology on the problem of teaching educational subjects of spiritual-moral direction at the general-course department of educational institution management and pedagogics of the higher school was organized the intense collaboration between teachers in students on elaboration of the correspondent educational programs.

Realization of magisterial program on aforesaid speciality presupposed involvement of students and teachers in management of spiritual-moral processes in the higher school. So, scientific-pedagogical workers and students took part in planning, organization and carrying out of the common scientific-methodological events in the period of educational session: seminars, round tables, presentations of projects of spiritual-moral direction.

In Ukrainian humanitarian institute took part the student scientific-methodological seminar "Actual problems of spiritual-moral education of students in Ukraine". The participants of seminar noted that the appearance of speciality "Christian pedagogics in the higher school" is an important event for Christian education in Ukraine. At the seminar was analyzed the future collaboration of educational institutions, possibility of combina- tion in the modern world of scientific-pedagogical activity and serving, possibility of signing an agreement about friendship, collaboration and partnership between the Ukrainian humanitarian institute and University of education management, participation in the common student social projects "Kapitoshka", "Family circle", public organizations "Center of help to pregnant", "Dobropillya parents committee", "Sumy regional organization of pedagogues-Christians", social programs "Sixteen days against violence", "Independence school", "Health country", "Adrenalin" - program for teenagers about the harmfulness of drugs, alcohol, smoking, "Manna in the city" and so on.

The powerful factor of scientific-methodological seminar became the signing of agreement about collaboration between the institutes and accepting decisions about introduction of educational subjects of spiritualmoral direction at all HEI specialities that favored the possibility of combination of professional and spiritual education, realization of Christian principles in professional activity. In 2016 year the social component was added to these subjects that is participation in serving to the people, city, country.

The future teachers of Christian pedagogics noted that their self-realization can take place in every moment of everyday life transforming it from the routine to the attracting travel in space and time. Striving for realization of the spiritual feat can be fulfilled by the ways of permanent self-improvement, construction of the more perfect life according to the values and ideals common to mankind, help to people who need it, that can be not only material one - sometimes the demonstration of care, attention to the youth is vitally important for it; filling the informational space with highly spiritual ideas, works of art.

\section{Conclusions}

So, the analysis of the modern tendencies and problems of the theory of spiritual-moral processes management in the higher school needs the new view on the spiritual-moral development of both person and society, needs the new understandings of internal deep transformation and self-improvement with priority manifestation of the highest spiritual-moral values common to mankind. That is why there are necessary the further researches of the problem of formation of conceptual principles and methodology of HEI management as the following: elaboration of strategy of student spiritual-moral education; approbation of the new educational and managerial technologies of spiritual-moral content and its introduction to the HEI educational process; the search for the optimal combination of forms and technologies of spiritual and secular education; reengineering of business-processes in HEI; vertical and horizontal development of integrative processes especially with foreign educational institutions and other organizations.

The problem of interaction of spiritual and secular educational systems is considered first off all in coordinates of moral sanitation and spiritual enlightenment of the nation, construction of democratic grounds of society and elaboration of the modern theory of spiritual-moral processes management in the higher school. The ponderability of the secular and spiritual components balance in 
higher school educational process is caused by the necessity of teaching students of the tolerant attitude to the otherness, formation of feeling of the own participation in correspondent cultural-spiritual tradition and necessity to verify the own life by its value orientations.

The prospect of research is the elaboration of the main functions that must establish the main claims to production tasks in professional activity of the holder of pedagogical master's degree on speciality "Christian pedagogics in the higher school".

\section{References}

1. Kononenko, V. Derzhavna politika in gumanitarniy osviti [Text] / V. Kononenko // Derzhavna politika in gumanitarniy sferi: materiali kruglogo stolu. - Ivano-Frankivsk, 2001. - P. 10-14.

2. Grinevich, L. M. Kozhen rano chi pizno pruxodut to Boga in svoemu zhitti [Text] / L. M. Grinevich // Slovo Vchitelyu. - 2016. - Vol. 1. - P. 3-5.

3. Bech, V. Gumanitarny rozvitok krainu: vnutrishnya politika der zhavi u suchasnomu globalizovanomu sviti [Text] / V. Bech // Derzhavna politika in gumanitarniy sferi (materiali kruglogo stolu). - Ivano-Frankivsk, 2001. - P. 3.

4. Sotsialno-gumanistichny potentsial natsionalnoi svidomosti [Text] /za zag. red. V. I. Lugovogo, V. M. Knyazeva. - K.: Vud-vo of NADU, 2005. - P. 29-34.

5. Kremen, V. G. Filosofiya lyudinotsentrizmu in strategiyah osvitnogo prostoru [Text] / V. G. Kremen. - K.: Pedagogichna dumka, 2009. $-520 \mathrm{p}$.

6. Skurativsky, V. Gumanitarna politika in Ukraini [Text]: navch. posib. / V. Skurativsky, V. Troschinsky, S. Chukut. - K.: Vud-vo of UADU; Vud-vo «Milenium», 2002. - P. 32-33.

7. Andruchenko, V. Osvita mae plekati duhovnist [Text] / V. Andruchenko // Nauk. chasopis NPU im. M. P. Dragomanov. Ser. 7: Religieznavstvo. Culturology. Filosofiya. 2007. - Vol. 11, Issue 24. - P. 3-7.

8. Kutsenko, V. J. Duxovna kontseptsiya upravlinnya of trudovum collectives [Text] / V. J. Kutsenko // Ekonomika i organizatsiya upravlinnya. - 2014. - Vol. 3-4, Issue 19-20. -P. 150-155.

9. Nadolny, I. F. Realizatsiya derzhavnoi kulturnoi politiki yak prioritetny napryam rozvitku gumanitarnoi sphere [Text] / I. F. Nadolny, V. A. Rebkalo, N. R. Nizhnik et. al. K.: Vud-vo of UADU, 2000. - P. 200-210.

10. Natsionalna strategiya rozvitku osviti in Ukraini for 2012-2021 roki [Electronic resource]. - Available at: http:// www.meduniv.lviv.ua/files/info/nats_strategia.pdf

11. Kremen, V. G. Filosofiya natsionalnoi idei. Lyudina. Osvita. Sotsium [Text] / V. G. Kremen. - K.: Gramota, 2007. $-576 \mathrm{p}$.

12. Ryabenko, Je. M. Principe lyudinotsentrizmu in upravlinni vischoyu osvitoyu: motivatsiyni aspects profesiynoi diyalnosti vikladacha yak sub'ekta osvitnogo process [Text] /
Je. M. Ryabenko // Gumanitarny visnuk ZDIA. - 2013. Vol. 56. - P. 33-42.

13. Katerynchuk, O. V. Modernizatsiya sistemi osviti [Text] / O. V. Katerynchuk // Available at: http://intkonf.org/ katerinchuk-ov-modernizatsiya-sistemi-osviti/

14. Rivny dostup to yakisnoi osviti (zvit for purshia etap) [Electronic resource]. - Programa pidtrimki viroblennya strategii reformuvannya osviti. - Available at: http://www. irf.ua/files/ukr/programs_edu_ep_329_ua_eaqefv.doc

\section{References}

1. Kononenko, V. (2001). Derzhavna politika in gumanitarniy osviti. Derzhavna politika in gumanitarniy sferi: materiali kruglogo stolu. Ivano-Frankivsk, 10-14.

2. Grinevich, L. M. (2016). Kozhen rano chi pizno pruxodut to Boga in svoemu zhitti. Slovo Vchitelyu, 1, 3-5.

3. Bech, V. (2001). Gumanitarny rozvitok krainu: vnutrishnya politika der zhavi u suchasnomu globalizovanomu sviti. Derzhavna politika in gumanitarniy sferi (materiali kruglogo stolu). Ivano-Frankivsk, 3.

4. Lugovoi, V. I., Knyazev, V. M. (Eds.) (2005). Sotsialno-gumanistichny potentsial natsionalnoi svidomosti. Kyiv: Vud-vo of NADU, 29-34.

5. Kremen, V. G. (2009). Filosofiya lyudinotsentrizmu in strategiyah osvitnogo prostoru. Kyiv: Pedagogichna dumka, 520.

6. Skurativsky, V., Troschinsky, V., Chukut, S. (2002). Gumanitarna politika in Ukraini. Kyiv: Vud-vo of UADU; Vud-vo «Milenium», 32-33.

7. Andruchenko, V. (2007). Osvita mae plekati duhovnist. Nauk. chasopis NPU im. M. P. Dragomanov. Ser. 7: Religieznavstvo. Culturology. Filosofiya, 11 (24), 3-7.

8. Kutsenko, V. J. (2014). Duxovna kontseptsiya upravlinnya of trudovum collectives. Ekonomika i organizatsiya upravlinnya, 3-4 (19-20), 150-155.

9. Nadolny, I. F., Rebkalo, V. A., Nizhnik, N. R. et. al (2000). Realizatsiya derzhavnoi kulturnoi politiki yak prioritetny napryam rozvitku gumanitarnoi sphere. Kyiv: Vud-vo of UADU, 200-210.

10. Natsionalna strategiya rozvitku osviti in Ukraini for 2012-2021 roki. Available at: http://www.meduniv.lviv.ua/ files/info/nats_strategia.pdf

11. Kremen, V. G. (2007). Filosofiya natsionalnoi idei. Lyudina. Osvita. Sotsium. Kyiv: Gramota, 576.

12. Ryabenko, Je. M. (2013). Principe lyudinotsentriz$\mathrm{mu}$ in upravlinni vischoyu osvitoyu: motivatsiyni aspects profesiynoi diyalnosti vikladacha yak sub'ekta osvitnogo process. Gumanitarny visnuk ZDIA, 56, 33-42.

13. Katerynchuk, O. V. Modernizatsiya sistemi osviti. Available at: http://intkonf.org/katerinchuk-ov-modernizatsiyasistemi-osviti/

14. Rivny dostup to yakisnoi osviti (zvit for purshia etap). Programa pidtrimki viroblennya strategii reformuvannya osviti. Available at: http://www.irf.ua/files/ukr/programs_edu_ ep_329_ua_eaqefv.doc

Дата надходження рукопису 18.02.2016

Sidanich Iryna, Doctor of pedagogical sciences, Professor, Department of management of educational institutions, Educational and Research Institute of Management and Psychology SHEE "Education Management University", Sichovyh Striltsiv str., 52-a, Kyiv, Ukraine, 04053 